This is an electronic reprint of the original article. This reprint may differ from the original in pagination and typographic detail.

Author(s): Tian, Meng; Risku, Mika; Collin, Kaija

Title: $\quad$ A meta-analysis of distributed leadership from 2002 to 2013 : Theory development, empirical evidence and future research focus

Year: $\quad 2016$

Version:

Please cite the original version:

Tian, M., Risku, M., \& Collin, K. (2016). A meta-analysis of distributed leadership from 2002 to 2013 : Theory development, empirical evidence and future research focus. Educational Management Administration and Leadership, 44(1), 146-164. https://doi.org/10.1177/1741143214558576

All material supplied via JYX is protected by copyright and other intellectual property rights, and duplication or sale of all or part of any of the repository collections is not permitted, except that material may be duplicated by you for your research use or educational purposes in electronic or print form. You must obtain permission for any other use. Electronic or print copies may not be offered, whether for sale or otherwise to anyone who is not an authorised user. 


\title{
A Meta-analysis of Distributed Leadership from 2002 to 2013:
}

\section{Theory Development, Empirical Evidence and Future Research Focus}

\author{
Meng Tian \\ Doctoral Student \\ Institute of Educational Leadership University of Jyväskylä \\ meng.tian@jyu.fi +358 408053653 \\ Address: Viveca 452, Rautpohjankatu 8, University of Jyväskylä, PO Box 35, \\ Jyväskylä, 40014, Finland
}

\section{Mika Risku}

Director of the Institute of Educational Leadership Institute of Educational Leadership University of Jyväskylä mika.risku@jyu.fi +358400247420

\section{Kaija Marjukka Collin}

Senior researcher, Adjunct professor (Adult education)

Department of Education University of Jyväskylä kaija.m.collin@jyu.fi +358400248058 


\title{
A meta-analysis of distributed leadership from 2002 to 2013: Theory development, empirical evidence and future research focus
}

\author{
Abstract \\ This article provides a meta-analysis of research conducted on distributed leadership \\ from 2002 to 2013. It continues the review of distributed leadership commissioned by \\ the English National College for School Leadership (NCSL) (Bennett et al., 2003), \\ which identified two gaps in the research during the1996-2002 period. The review \\ found that the studies had been unable to conceptualise distributed leadership or \\ empirically outline its application. The two research gaps identified by Bennett et al. \\ (2003) constitute the focus of the present review, which attempts to determine whether \\ recent research has been able to fill these gaps. Based on the findings of the present \\ meta-analysis, the authors recommend directions for future studies on distributed \\ leadership.
}

\section{Keywords}

distributed leadership, leadership as resource, leadership as agency, meta-analysis

\section{Introduction}

Since the mid-1990s, one of the most significant discussions concerning educational leadership has involved distributed leadership (Bolden, 2011; Bush, 2013; Elmore, 2003; Gronn, 2000; Harris, 2007; Hartley, 2007, 2009). Distributed leadership first emerged as a pragmatic tool that allowed leaders to share their increasing workload. The concept was later applied to the leadership influence of other actors (Gronn, 2002; Robinson, 2008; Spillane, 2006; Storey, 2004). At the beginning of the millennium, 
Bennett, Wise, Woods and Harvey (2003) commissioned by the English National College for School Leadership (NCSL) conducted a meta-analysis of distributed leadership studies published from January 1996 to July 2002. Its findings indicated two major gaps in the research: the failure to both clarify the concept of distributed leadership and empirically define its application.

The present article attempts to determine how the research after 2002 until 2013 had tried to fill the two gaps identified by Bennett et al. (2003) and to propose how distributed leadership could be studied in the future.

\section{Methodology}

Because the starting point of the present meta-analysis was Bennett et al.'s (2003) review our preliminary intention was to follow the same methodology. However, over the past decade, the concept of distributed leadership in education had gained a lot of unprecedented independence and popularity (Bolden, 2011). Consequently, an increased number of studies on distributed leadership were conducted between 2002 and 2013, compared to the period between 1996 and 2002. Because of this fundamental change in context, the methodology was designed quite differently. Although Bennett et al. (2003) included most studies that were published at that time, we were compelled to select the most representative ones for our review.

In the methodology used in Bennett et al.'s (2003) review, the first step consisted of an extensive literature search, using a wide range of keywords connected with distributed leadership. The search was later confined to studies published from 1996 to 2002. Publications with fewer than five pages were also excluded from the selection. 
Furthermore, only one publication by each author was included in the review. Finally, the selected publications were filtered using four keywords: delegated leadership, democratic leadership, dispersed leadership and distributed leadership. Ultimately, 80 publications were selected for the review.

The methodology of the present article comprised five steps. First, preliminary investigations determined the range of the number of publications on distributed leadership. The initial search revealed that over 720,000 articles had been published between 2002 and 2013. The second step consisted of finding the most representative publications. For this purpose, the focus was switched from articles to journals; both the Elton Bryson Stephens Company (EBSCO) and Education Resources Information Centre (ERIC) search engines in education were used to identify peer-reviewed journals that frequently published studies in English on distributed leadership. Eight peer-reviewed educational journals were identified.

Third, an examination was conducted to determine the number of articles on distributed leadership that were published in these eight journals between July 2002 and October 2013. Consequently, 823 articles were obtained from the following journals:

Educational Management, Administration \& Leadership (174), Education

Administration Quarterly (72), Journal of Research on Leadership Education (28), Journal of Cases in Educational Leadership (18), Management in Education (76), School Leadership and Management (229), Journal of Educational Administration (188) and British Journal of Sociology of Education (38). 
Fourth, the titles, keywords and abstracts of the 823 articles were examined to identify those that dealt with the two gaps in distributed leadership research found in Bennett et al.'s (2003) review. Consequently, 379 articles dealing with either the conceptualisation and/or the application of distributed leadership were identified.

The fifth and final step consisted of two phases. First, articles that did not deal with primary or secondary education were excluded from the review. Thus, the perspective of the present meta-analysis was somewhat more confined than that of Bennett et al.'s (2003) review. On one hand, a much larger number of studies were available; on the other hand, our goal was to provide a meta-analysis that better served further studies focusing on distributed leadership in primary and secondary education. Second, criteria were established to select the most representative articles. It was decided that only articles that had been cited at least 50 times would be selected for the review. During the examination of the selected articles, it was noted that some articles and book chapters that were published in other channels had been extensively cited by the selected articles. Thus, these articles and book chapters also were considered representative of the examined period and were included in the final selection.

The selection process yielded 85 articles and book chapters, of which 53 dealt with the conceptualisation of distributed leadership and 32 focused on the application of distributed leadership. Each of these articles is marked with an asterisk $\left(^{*}\right)$ on the reference list. 
In order to avoid personal biases, a review protocol was established, which comprised a structured table for collecting and categorising the key information from each article. The table included items such as the research subject, context, methodology and key findings. Regular meetings were held to discuss individual findings and confirm similar interpretations of the readings.

\section{Two focus areas and two paradigms in distributed leadership research}

Bennett et al.'s (2003) review focused on two areas in the research on distributed leadership: conceptualisation and application. This review pointed out that the primary challenge in the research was the absence of an explicit and commonly accepted definition of the concept. In its initial stage, distributed leadership was mainly perceived as an analytical lens to observe the interactions among people when they enacted leadership work (Bennett et al., 2003: 8). In addition to the absence of a solid theoretical foundation, the lack of empirical evidence on the practices and effects of distributed leadership was identified as another research gap, which thus constituted the second focus of future research.

The search methodology used in the present review identified 85 publications that concentrated on the two focus areas identified by Bennett et al. (2003). Concerning the operationalization and dimensions of distributed leadership, the lack of clear agreement notably persisted. However, two examples found during the analysis provided interesting perspectives for future studies on distributed leadership. The first example was a study by Woods, Bennett, Harvey and Wise (2004), the same group of researchers who carried out Bennett et al.'s (2003) review. They applied Archer's 
(1995) structure-agency analytical dualism to categorise the 32 publications they had examined in Bennett et al.'s (2003) review. According to them, studies adopting a structural view tended to examine "the distribution of resources and responsibilities, cultural ideas and values, as well as social relations' (Woods et al., 2004: 450). On the other hand, studies from the point of view of agency examined the actions and interactions of people in taking initiatives, making choices and participating in leadership work. Although Bennett et al. (2003) and Woods et al. (2004) examined the same pool of literature, their foci differed. Due to its design Woods et al. (2004: 450) explicitly pointed out that distributed leadership had both structural and agential dimensions and that in practice, these two dimensions would often interact. Bennett et al. (2003), on the other hand, in their recommendation for future research focused on the structural dimension of distributed leadership.

The second example was the study of Hartley (2010), who adopted Burrell and Morgan's (1979) sociological typology to evaluate a series of pragmatic studies, finding that the majority of distributed leadership research fell under the social regulation dimension, not radical change. Hence, according to Hartley (2010), most of these studies had tried to understand and interpret distributed leadership instead of seeking change through it.

Neither the structure-agency dualism nor the sociological typology or any other research categorisation we recognised in the 85 articles directly examined distributed leadership from the angle of the two gaps identified by Bennett et al. (2003). However, 
as earlier stated, both the structure-agency dualism and the sociological typology proved to offer interesting perspectives for future studies as the analysis proceeded.

Although the individual articles examined in the present meta-analysis did not specifically aim at filling the two research gaps identified by Bennett et al.'s (2003) review, overall they shed much light on both of them. In fact, two corresponding research paradigms could be inferred from the articles. The first paradigm emerged from the 53 articles that mainly dealt with the conceptualisation of distributed leadership. It was labelled as a descriptive-analytical paradigm because it seemed to aim at providing an understanding and interpretations of the concept of distributed leadership. The second paradigm arose from the 32 publications attempting to present prescriptions for and best practices of distributed leadership in daily school operations. It was named a prescriptive-normative paradigm since it focused on the practical application of distributed leadership.

Studies in the descriptive-analytical paradigm tended to assume that leadership was already distributed, not reflecting on whether it should be distributed (Gronn, 2002, 2003; MacBeath, 2005; Mayrowetz, 2005, 2008; Spillane, 2006). By presupposing that distributed leadership was a phenomenon that naturally existed in schools, these studies aimed at dissecting the components and processes of leadership practice in order to expand and deepen the understanding of leadership work (Gronn, 2002, 2003, 2008a; Mayrowetz, 2005; Spillane et al., 2004; Spillane, 2006; Timperley, 2005; Woods et al., 2004). 
Research in the descriptive-analytical paradigm focused on examining various kinds of social interactions in schools. It perceived leadership as an emergent characteristic created by social interactions. Traditional leadership theories that narrowly examined the causal relationships between officially designated leaders and organisational effectiveness were openly challenged. Not just official leaders but any school member and even artefacts were considered as having the ability to exert leadership influence on activities (Gronn, 2003; Spillane et al., 2004; Spillane, 2006).

In the descriptive-analytical paradigm, common research questions included: What does leadership mean to you (Gronn, 2009: 25)? Who are the formal and informal leaders? What constitutes a leadership task (Spillane et al., 2004: 13)? The answers to these questions involved capturing key tasks, actors, actions and interactions of distributed leadership.

Studies under the prescriptive-normative paradigm seemed to have won a lot of popularity over the past decade. Harris' (2009b: 265) statement that schools in the 21st century needed to proactively design 'fluid, organic structures premised on widely distributed forms of leadership' illustrated the belief in the pragmatic value of distributed leadership. Hargreaves and Fink (2008) continued in the same line of thinking, arguing that distributed leadership was a more sustainable approach in the contemporary complex and fast-changing world, but they also advised that distributed leadership should be tightly connected to schools' core work, learning. In the reviewed articles, studies in this paradigm mainly focused on identifying those distributed leadership patterns that seemed to exert positive impacts on school improvement and 
on trying to provide norms and prescriptions to guide practice (Harris, 2004, 2008, 2009b, 2012; Leithwood, Mascall and Strauss, 2009a).

Research in the prescriptive-normative paradigm explored the practices and effects of distributed leadership from the utilitarian viewpoint. Articles in this paradigm did not necessarily claim that distributed leadership was intrinsically an effective model by default (Day, Sammons, Hopkins, Harris, Leithwood, Gu, Brown, Ahtaridou and Kington, 2009; Harris, 2012); however, they were inclined to find out those distributed leadership patterns that might effectively contribute to school improvement (Camburn, Rowan and Taylor, 2003; Copland, 2003; Hargreaves and Fink, 2008; Harris, 2005, 2012; Mayrowetz, Murphy, Louis and Smylie, 2009, Timperley, 2005, 2009).

Research questions that prescriptive-normative researchers raised include: How can leadership be distributed in order to maximally benefit the school practice (Bolden, 2011)? How does distributed leadership develop leaders who serve the knowledge creation (Harris, 2009b)?

As the next two sections show, over the past decade, research employing either the descriptive-analytical or the prescriptive-normative paradigm had failed to completely fill the two research gaps identified by Bennett et al.'s (2003) review. These studies remained unable to define distributed leadership in a universally accepted way or to offer enough knowledge about its effects and ideal forms.

\section{Filling the gap of conceptualising distributed leadership}


Based on the 53 articles representing studies on the conceptualisation of distributed leadership, three main approaches were identified: modelling distributed leadership practice, comparing distributed leadership with similar concepts and questioning the concept of distributed leadership.

Concerning modelling distributed leadership practice, two models were considered to have exerted profound influence on the conceptualisation of distributed leadership. The first one was Spillane's (2006: 3) practice-centred model, consisting of leaders, followers and situation as the key components and indicating that 'collective interactions among leaders, followers and their situation are paramount' for distributed leadership practice (2006: 4). Notably, Spillane's practice-centred model highlighted distributed leadership as going beyond shared leadership, because it not only comprised the leader-plus aspect (i.e. multiple individuals function as leaders) but also the practice aspect (i.e. leadership generated from interactions).

Spillane's (2006) model seemed to have fundamentally changed the unit of analysis from people to practice. He also tested his model empirically and identified four distributed leadership patterns: collaborative, collective, coordinated and parallel. From an analytical-descriptive angle, these patterns offered a logical categorisation of how leadership was distributed in practice.

Gronn $(2002,2003)$ built the second highly influential model on the conceptualisation of distributed leadership. At the beginning of the millennium, he had established the numerical-concertive model, which resembled Spillane's (2006) leader-plus and 
practice-centred aspects. After reviewing a number of empirical studies, he later proposed the hybrid model as a more appropriate descriptor for distributed leadership because it fused 'hierarchical and heterarchical elements' (Gronn, 2008a: 155). One major contribution of Gronn's hybrid model was that it detached distributed leadership from the individual-collective and formal-informal leadership continuums. The model admitted that individual leaders were equally significant and simultaneously co-existed with collective forms of leadership. Additionally, because distributed leadership would evolve over time and differed from one context to the other, it had no fixed pattern.

Compared to Spillane (2006), who examined distributed leadership as the conjoint agency of multiple actors, Gronn (2008a, 2009) to some extent acknowledged leadership also as individual agency in his hybrid model. However, Gronn's main interest was to delineate how different sources of agency would constitute the holistic leadership pattern. Neither Spillane's nor Gronn's model examined how individuals would feel, participate and develop in the leadership process.

Modelling distributed leadership practice seemed to have provided theoretical foundations for empirical studies. The models asserted that an organisation's sustainable development relied on multiple sources of leadership and regarded the formal leaders' role not as that of an absolute authority, but more of a coordinator who utilised others' expertise (Spillane, 2006; Gronn, 2008a). The scope of distributed leadership had gradually been expanded from task sharing to collective interactions and then to a hybridity of individual and collective, hierarchical and heterarchical leadership forms, which could be utilised as frameworks for empirical studies. 
Concerning the comparison of concepts, no systematic analysis was found to solely concentrate on delineating the conceptual boundaries between distributed leadership and other related concepts. There even seemed to be some concerns that distributed leadership would be used interchangeably with similar concepts. For example, Harris (2007) argued that using distributed leadership as a catch-all concept for any form of devolved, shared or dispersed leadership might lead to misunderstandings in research, policymaking and practice. By quoting Spillane's (2006) practice-centred model, Harris asserted that in contrast to shared leadership, which perceived leadership as an aggregated agency created by multiple individuals, distributed leadership was essentially about practice, not people. Later, Heikka, Waniganayake and Hujala (2012: 34) explicitly pointed out that shared leadership focuses on micro-level teams, while 'distributed leadership adopts a more macroscopic view of organisation'.

A similar comparison among teacher leadership, team leadership and distributed leadership surfaced from the review. The first two, as their names would suggest, might be expected to adopt a people-centred perspective by studying teachers' or teams' roles and functions. However, although quite a few of the reviewed studies investigated distributed leadership from the perspective of teachers (e.g. Camburn et al., 2003; Chang, 2011; Law, Galton and Wan, 2010) and teams (e.g. Hulpia, Devos and Rosseel, 2009a; Pedersen, Yager and Yager, 2012; Scribner et al., 2007; Sentocnik and Rupar, 2009; Timperley, 2009; Wallace, 2002), they generally did not focus on studying the role of teachers or teams but were confined to the interactions among different levels in the school hierarchy through people and teams. In other words, the studies focused 
more on the resources which emerged from teacher and team leadership than on the agency which teacher or team leadership allowed.

The third example on comparisons concerns the one between distributed and democratic leadership. Spillane (2006) and Woods (2004) claim that distributed leadership could be both democratic and autocratic. As earlier described, Spillane's (2006) distributed leadership model focused on interaction and how it manifested itself in school work. His longitudinal studies revealed that formal leaders played a dominant role in boosting informal leadership (Spillane, Camburn and Pareja, 2007; Spillane, Diamond and Jita, 2003; Spillane and Healey, 2010) but did not question the power relationship as such. Particularly, Spillane and Healey's (2010) perspective was organisational and regarded leadership as a resource. They closely examined the formal and informal dimensions of the school organisation, but how the power relationship affected individuals' agency gained little attention.

On the other hand, research on democratic leadership by Woods (2004, 2011, 2013), as well as by Woods and Woods (2013) did not suffice to identify the democratic nature of leadership but also aimed at using human potentials to serve people's holistic well-being. Thus, how leadership would manifest itself as individuals' agency was one of the foci. Democratic leadership incorporated meaningful participation in decision making as well as personal growth; thus, it had a more normative perspective than distributed leadership. 
The third identified approach to fill the gap of conceptualisation involved researchers' critical voices on distributed leadership. For example, Johnson (2004) warned that distributed leadership might be camouflaged as a micro-political strategy to rationalise top-down management. Thus, how leadership would be distributed might be manipulated, and distributions might serve some people's interests only. Most studies on the subject seemed to examine the effectiveness of distributed leadership from the organisational perspective, neglecting the scope of how individuals could exert agency during the process. This pitfall was further deepened by Woods (2004, 2005, 2011) in his holistic democracy model. He claimed that distributed leadership was grounded in a narrow understanding of the human being, which primarily focused on developing people's intellectual and psychological dimensions. Thus, it was often measured with calculable outcomes such as test scores and financial performance and did not necessarily consider the ethical foundation of leadership (Woods and Woods, 2013). Furthermore, Lumby (2013: 583) criticised the literature on the subject for tending to avoid 'problematizing power and its relationship to distributed leadership'. She argued that ignoring politics in education actually made distributed leadership a political phenomenon, to 'replete with the uses and abuses of power' (Lumby, 2013: 592).

It can be concluded that over the past decade, research seemed to have enriched the discussion to fill the gap of conceptualising distributed leadership but had not yet reached a consensus on what distributed leadership is. Moreover, research tended to have focused on examining leadership more as a resource from an organisational point 
of view than as an agency that allowed individuals to have an active role in the organisation.

\section{Filling the gap on the application of distributed leadership}

As a result of the search process, 32 articles were reviewed concerning the research gap on the application of distributed leadership. The articles represented 23 studies in five continents and 19 countries, thus providing a broader geographical and cultural spectrum than the ones on the conceptualisation of distributed leadership. Those studies almost solely represented research conducted in the Anglo-American world.

At the beginning of the millennium, distributed leadership seemed to have been a novel phenomenon, with limited studies on the topic. For this reason, Bennett et al.'s (2003) review included studies from education, social community, public service and business settings. As mentioned in the methodology section, because of the abundant relevant literature over the last ten years and with the parallel aim of forming a research background for a distributed leadership study in primary and secondary education, this meta-analysis reviewed studies conducted solely in those two educational levels.

Similar to the research quantity, the scale and methodology of distributed leadership studies also seemed to have evolved over the last decade. Bennett et al.'s (2003: 6) review mostly comprised 'small-scale qualitative case studies'. The present meta-analysis found more variation. Of the 23 studies, 21 were empirical and two were meta-analyses. Of the 21 empirical studies, six used a qualitative approach, featuring interviews, observations, and case studies; seven adopted a quantitative method based on surveys; five employed mixed methods and three were comparative. 
As earlier described, studies on distributed leadership have become more global, making the research findings more versatile and complicated. In fact, the versatile results may indicate that there are few universal answers and that how distributed leadership is interpreted and subscribed to in practice is heavily shaped by the social-cultural contexts. Thus, the findings of the following studies cannot be regarded as universal truths but should be examined in various contexts to obtain broader verification.

Three main approaches to tackle the gap in the application of distributed leadership were identified: examining the favourable conditions for distributed leadership, evaluating the effects of distributed leadership applications and recognising potential risks of applying distributed leadership.

Concerning favourable conditions, several studies found four key elements that seemed to nurture distributed leadership in schools: formal leaders' support, climate of trust, strategic staff policy and utilisation of artefacts in leadership. Research in this area often seemed to examine leadership both as a resource from the organisational standpoint and as an agency from the individual one, as the following review shows.

Regarding formal leaders' support, research seemed to indicate that informal leadership was tightly linked to and significantly shaped by formal leadership (Angelle, 2010; Dinham, Aubusson and Brady, 2008; Hulpia, Devos and Van Keer, 2009c; Jing, 2010; Law et al., 2010; Leithwood et al., 2007; Spillane and Healey, 2010; Wright, 2008). Moreover, empirical evidence tended to reaffirm that schools with only one power 
centre and a steep hierarchy led to poor performance and low morale (Oswald and Engelbrecht, 2013; Williams, 2011).

In a distributed leadership setting, formal leaders should also be regarded as important 'gate keepers' who either encourage or discourage others from leading and participating in organisational changes. For example, a Canadian study (Bush and Glover, 2012) showed that the effectiveness of distributed leadership strongly depended on the principal's intentional support. In a successful distributed leadership setting, school staff also tended to acknowledge informal leaders who shared similar traits and dispositions with formal leaders (Leithwood et al., 2007). Studies such as these can be deemed to examine leadership not only as an organisational resource but also as an individual agency. This agency often seems to be created by the principals who first demonstrate it themselves by intentionally creating leadership opportunities for others. In return, teachers practise their agency by acting as informal leaders and acknowledging other informal leaders.

In line with the sociological typology emphasising distributed leadership as a tool for change, prescriptive-normative research urges principals to allow fundamental changes in school leadership so that formal and informal leadership are not oppositional but compatible (Harris, 2013a). In such a setting, it seems that principals' power and authority should be determined in relation to the overall leadership resources in schools, as Hong Kong, Australia and South Africa already seem to be doing (Lee, Hallinger and Walker, 2012; Leithwood et al., 2007; Williams, 2011). Additionally, prescriptive-normative research challenges principals to acknowledge alternative 
sources of leadership in their organisations (Lee et al., 2012; Murphy, Mayrowetz, Smylie and Louis, 2009; Wright, 2008). The application of distributed leadership tends to encourage principals to consciously facilitate and support leadership from others. Finally, to succeed in the distribution of leadership, it seems that schools' daily routines should be redesigned so that both formal and informal leadership can flourish and be sustained (Ban Al-Ani and Bligh, 2011; Gunter, Hall and Bragg, 2013; Harris, 2013b; Spillane et al., 2007). As a case in point, a Belgian study implied that leaving teacher teams to work alone without the principal's regular supervision may lead to low effectiveness (Hulpia, Deveos, Rosseel and Vlerick, 2012).

The studies on the application of distributed leadership suggested the essential aspect of the climate of trust for distributed leadership, yet how trust would be established seemed to vary among different cultural settings. Oduro's (2004) data from 11 primary and secondary schools in England showed trust as the most frequently and commonly mentioned factor for promoting distributed leadership. He found out that trust enabled principals to distribute leadership, not only through formal task delegation but also through informal empowerment. The prerequisite appeared to be teachers' ability to demonstrate their trustworthiness in enacting leadership work. Jing's (2010) comparative study indicated that in Chinese schools, trust would first be built upon interpersonal relationship, then on pedagogical competence and finally, on leadership experience. Distributing leadership in Chinese schools might encounter cultural barriers if it would disturb the harmonious interpersonal relationships. In contrast, in American schools, trust mostly tended to come from leadership competencies, which 
appeared tightly connected to a specific expertise. American teachers thus seemed to accept expertise-based distributed leadership fairly easily (Jing, 2010).

Strategic staff policies seemed to provide fluidity and flexibility in organisational structures. Findings debunked the myth that distributed leadership aimed to abolish organisational hierarchy and reaffirmed the perception that distributed leadership allowed practitioners to utilise human resources more innovatively. For example, in a Hong Kong case study, leaders' roles were intentionally rotated from official leaders to committed teachers (Law et al., 2010). The leadership role rotation seemed to boost teachers' confidence in using their professional knowledge in curriculum work. Teachers also became more engaged when they were invited into the decision-making process. As another example, in a comparison of five International Baccalaureate (IB) schools in mainland China, Hong Kong, Thailand and Vietnam (Lee et al., 2012), three staff strategies emerged from the data: recruiting teachers who shared similar professional backgrounds, putting key persons in several programmes and regularly switching teachers' positions. Lee et al. (2012) claimed that purposeful recruitment, multiple positioning and position switching ensured the availability of the instructional resource and professional support at all levels of the school. They also pointed out international schools as ideal research contexts for distributed leadership studies due to their greater degree of freedom to try new structures than ordinary schools had.

The utilisation of artefacts seemed to expand the operational sphere of leadership. Spillane (2006: 84) brought artefacts from the background to the centre of the stage, claiming that 'tools and routines are the vehicles through which leaders interact with 
each other or with followers'. A four-year consecutive research (Timperley, 2009) conducted in seven New Zealand schools indicated that school teachers accelerated students' outcomes by purposefully using artefacts (e.g. achievement data). The influence of artefacts appeared to expand the operational sphere of leadership in two ways. First, leadership would no longer follow a one-way direction from superiors to subordinates but proceed both ways, enabling subordinates to have agency and also exert influence on their superiors. Second, leadership does not limit itself to human-human interactions; it can also be displayed in human-artefact and human-artefact-human formats. Both Spillane (2006) and Timperley (2009) noted that in schools, artefacts had not yet been effectively used for leadership purposes or had even been misused to 'distort teaching practice' (Spillane, 2006: 80).

The second identified approach to fill the gap was to evaluate the effects of distributed leadership applications. Besides observing the effects, research in this area seemed to have obtained interesting information concerning leadership both as organisational resource and individual agency. As a starting point, the approach examined distributed leadership not only to understand it better, but also as a tool for change.

Over the past decade, one of the most heated debates involved whether or not distributed leadership could enhance students' learning outcomes. Despite the keen interest from academia, providing robust evidence to validate distributed leadership in relation to students' learning improvement appeared extremely difficult. A representative example is the study by Anderson, Moore and Sun (2009), whose two limitations were also experienced by other small-scale, distributed leadership case 
studies (e.g. Angelle, 2010; Timperley, 2009) - the difficulty of modelling the causal relationship between distributed leadership and student learning outcomes, and the problem of generalising the identified applications of distributed leadership at the macro-level.

Anderson et al.'s study (2009) attempted to investigate normative links between distributed leadership and students' three-year, standardised test scores in five British schools. Similar to many other small-scale case studies, the research failed to find direct correlations between distributed leadership and students' longitudinal test scores in all subjects. What it discovered was that students' test scores fluctuated over the years, which were attributed more to student and personnel mobility than to distributed leadership. The correlations with various subjects also varied. For example, in one of the studied schools, the improved test scores could be indirectly attributed to distributed leadership in reading and mathematics but not in science. Anderson et al. (2009:132) concluded that seeking direct measurable correlations between distributed leadership and students' learning outcomes might be less productive than exploring how distributed leadership would affect teachers' professional communities. Earlier studies had already proven that teachers contributed the most to students' learning outcomes, and the correlation between distributed leadership and teachers' effectiveness seemed to be more easily examined.

Only one large-scale research (Heck and Hallinger, 2010) on the correlation between distributed leadership and students' learning outcomes was found in the present meta-analysis. This four-year longitudinal study in 197 American primary schools 
seemed to have overcome the above-mentioned two limitations concerning small-scale studies on distributed leadership. Methodologically, the study had adopted the structural equation model (SEM) to investigate the impact of 'the changes in distributed leadership on changes in school improvement capacity and growth in student learning' (Heck and Hallinger, 2010: 868). The study provided distinct indicators for distributed leadership, school improvement capacity and student learning outcomes. Moreover, with the SEM technique, the researchers were able to incorporate missing data and student mobility into the analysis, thus reducing parameter bias. Based on their results, Heck and Hallinger (2010: 881) claimed that distributed leadership indirectly but significantly enhanced students' mathematics and reading performance.

As Anderson et al. (2009) recommended, most empirical studies looked for the effects of distributed leadership on teachers, rather than the direct relationship between distributed leadership and students' learning outcomes (e.g. Scribner, Sawyer, Watson and Myers, 2007; Watson and Scribner, 2005, 2007). A quantitative study of 46 secondary schools in Belgium (Hulpia et al., 2009a, Hulpia and Devos, 2009b) contended that distributed leadership might significantly enhance teachers' organisational commitment and job satisfaction when there was cohesion in the leadership team. School staff appeared to welcome support from both formal and informal leaders. However, teachers' commitment seemed to drop if multiple leaders supervised them. In a Finnish case, vocational school teachers broke the system-level boundaries to collaborate with other stakeholders such as social workers and 
employers in the labour market. Building a distributed leadership network within the educational system appeared to pave a smoother learning path and to prevent dropouts (Jäppinen and Maunonen-Eskelinen, 2012; Jäppinen and Sarja, 2012).

Moreover, as Leithwood et al. (2007) stated, the emergence of distributed leadership would not necessarily flatten the hierarchical structure or share undifferentiated leadership functions across different roles. On the contrary, distributed leadership would admit the co-existence of hierarchical and fluid structures. Furthermore, as Locke (2003) mentioned, the agency created by distributed leadership would not have the same impact for all actors because leadership functions were bound to position and legitimacy.

Although research suggested that distributed leadership might bring positive impacts on students' learning, teachers' morale and students' transition, some critics argued that such improvement may be rhetoric. These critics tried to fill the research gap by identifying the potential risks of applying distributed leadership. This constitutes the third research approach on the application of distributed leadership. It can be claimed that the approach strongly focuses on perceiving leadership as an individual agency.

Lumby (2013: 582) warned that distributed leadership 'reconciles staff to growing workloads and accountability' but in terms of the use of power, teachers' 'autonomy is offered with a leading rein'. On the other hand, Fitzgerald and Gunter (2006) questioned the ethical foundation of distributed leadership, arguing that luring teachers to do more work was a new form of managerialism. Woods and Woods 
(2013) also claimed that distributed leadership did not ontologically embed social justice and equity. Normative studies that evaluated distributed leadership via calculable indicators such as test scores might blind research from recognising the deeper value of school leadership work. These criticisms argued that the majority of distributed leadership studies merely examined leadership as an organisational resource that can be cultivated and utilised to serve school improvement. What they demanded was that individuals, especially teachers, who genuinely exercised their professional agency in decision making, should also be at the core of distributed leadership and its research.

It can be concluded that research on the application of distributed leadership, in the same way as that on the conceptualisation, has provided new information on distributed leadership but has not been able to fully fill the gap identified by Bennett et al.'s (2003) review. . The lack of a universally accepted definition of distributed leadership seems to complicate the task. The reviewed articles also indicate that different sociocultural contexts subscribe to distributed leadership in different ways; thus, using the same approaches in various contexts may provide diverse results (Feng, 2012). Additionally, students' learning outcomes depend on so many variables that it is challenging to underpin the correlation between them and distributed leadership.

Research on the application of distributed leadership has raised the issue of regarding leadership both as organisational resource and individual agency, though from a utilitarian perspective. It can also be argued that research in this area considers 
distributed leadership as a tool for change and does not merely examine it to gain a better understanding of its nature. The ethical foundation of distributed leadership has been heavily questioned as well. There seems to be an absence of research that tries to illuminate the use and misuse of power.

\section{Suggestions for future research}

This section comprises suggestions for future studies in distributed leadership. The recommendations are based on a definition of distributed leadership, which is designed according to the present meta-analysis and which we hope provides a starting point for a more general framework.

This article proposes that distributed leadership be defined and studied in terms of leadership as a process that comprises both organisational and individual scopes; the former regards leadership as a resource and the latter as an agency. Both resource and agency are considered to emerge and exist at all organisational levels.

\section{Leadership as resource}

In the context of the foregoing definition of distributed leadership, from an organisational perspective, the resource is vital for both its operations and development. The resource does not stay stagnant at the top of the organisational hierarchy but emerges and flows vertically and horizontally as the processes do. It is essential to try both to identify the resource and how it emerges. 
Based on existing research, the resource can refer to leadership created in the processes among people, artefacts and situations. In practice, people and artefacts are distributed at various levels of the school organisation, creating leadership in both formal and informal structures. Once meaningful interactions among different levels are built within and outside the organisation, new resources can emerge. As Harris (2009b) stated, organisations today rely increasingly on external networks. It is crucial to attempt to identify and describe the various manifestations of the resource more exclusively.

The examined research indicates that the relationship between the situation and the actors determines both the emergence and the nature of the resource. Earlier studies also listed some favourable conditions and ways of successfully establishing the resource. Nonetheless, much information remains unknown or unclear about the various situations and actors, their relationships and the processes in which the resource emerges. They should be the central foci of future research.

Besides being able to establish the leadership resource in an organisation, it is essential to cultivate it, on which future studies should also concentrate. The existing research has been able to provide some information to proceed with the studies. For instance, as Leithwood et al. (2009b) stated, distributed leadership is not just a tool to collect dispersed expertise, but also a means of further cultivating both people's and organisations' potentials. Leadership can be expanded and extended when more members of the organisation contribute their know-how. 
It is also noteworthy that perceiving distributed leadership solely from the standpoint of organisations may allow them to slip into a new type of managerialism (Johnson, 2004; Lumby, 2013) and decrease efficiency. Examining leadership from the perspective of individuals (as agency) is also needed to cultivate and use the organisational leadership resource efficiently.

\section{Leadership as agency}

In the context of the proposed definition of distributed leadership, for an individual, agency is a vital presupposition for the ability to have ownership, empowerment, self-efficacy and well-being in the organisation, both as an individual and through collective bodies. As Eteläpelto et al. (2013:61) argued, professional agency would allow 'professional subjects and/or communities [to] exert influence, make [a] choice and take stances in ways that affect their work and/or their professional identity'.

For example, Woods et al. (2004) recognised agency in connection to distributed leadership but generally, the results of the present meta-analysis indicate that the individual scope has not constituted the core of distributed leadership research. The focus has dominantly been on the organisational scope. However, future research should also underline the individual one and include agency. For instance, this claim is consistent with Leithwood and Mascall's (2008: 529) statement that the state-of-the-art strategy in leadership conversation is now moving towards 'distributed sources of influence and agency'. 
It is already known that in schools, distributed leadership entails a deliberate organisational redesign by the principal and purposeful engagement by the other school staff. Nonetheless, so far, researchers have been unable to clearly describe how different agents use their initiatives to influence leadership work. For example, research (Duif, Harrison, van Dartel and Sinyolo, 2013: 31) indicates that school leaders perceive teachers as not demonstrating enough initiative and responsibility in leadership. For their part, teachers attribute this issue to the lack of guidance and direction in school.

Distributed leadership research has not yet elaborated on what kind of agency school leaders can exert to create a supportive environment in which teachers can practise their agency to co-lead their school's daily operations. The research gap calls for a closer examination of the reciprocal relationship between professional agency and organisational improvement.

After a decade of evolution, distributed leadership is no longer a simple pragmatic solution to reduce official leaders' workload. It shows a greater potential to enhance school members' self-efficacy when their expertise is applied in particular leadership work (Day et al., 2009). Distributed leadership implies 'actively brokering, facilitating and supporting the leadership of others' (Harris, 2013b: 547). All these factors require professional agency from both the formal and informal leaders of a school. Therefore, we propose that future research on distributed leadership closely examines the social interaction process in which agency is exercised by various school members. 
The conceptualisation of agency presented in this article is based on a sociocultural approach that emphasises subjectivity at both individual and collective levels (see e.g. Eteläpelto et al., 2013). Leadership is considered to comprise multiple sources, including individual leaders, leadership teams and artefacts. Indeed, both the distributed leadership and professional agency theories admit that human beings are active and self-creating, despite their entanglement with the sociocultural practices, power relations and discourses in which they have to function (Davies, 2000; Fenwick, 2006). Therefore, professional agency is always practised in the sociocultural conditions of the workplace, such as in the practices, power relations, discourses and subject and role positions of a school (Clegg, 2006; Pyhältö, Pietarinen and Soini, 2012). This fact may provide meaningful insights to explain why and how micro-politics manipulate distributed leadership (Fitzgerald and Gunter, 2006; Jacobson, 2004).

The concept of professional agency includes two aspects: the individual, which is determined by the will to act, and the social, which includes an opportunity to act $(\mathrm{Ci}$, 2011). When both aspects are present, professional agency is possible (Caldwell, 2007). Individuals act in structures and organisations; at the same time, they build and change their surroundings (Battilana, 2006; Berger and Luckmann, 1991). Although a few existing studies have to some extent adopted the agency scope, their main focus has been on the individual instead of the social aspect. These studies have been primarily interested in measuring the end results of school members' agency such as task fulfilment and goal attainment. The social aspect of professional agency, which 
concerns its emergence and process, has not yet gained enough attention in distributed leadership research. As Woods and Woods (2013) pointed out, the fuller conceptualisation of the human being would transcend the cognitive, emotional and aesthetic capacities. Leadership shall also serve the human being's social needs, including the sense of connectedness, spiritual awareness and relational consciousness. This individual-social dualism from the professional agency theory may provide an analytical framework to deepen the concept of distributed leadership. Particularly, the combination of distributed leadership and professional agency theories may help researchers explore how to build a reciprocal relationship and a supportive environment in which school members are willing to contribute their professional expertise to leadership work while enhancing their self-efficacy and professional capacity. Professional agency is needed for employees to build a shared understanding of the creation of new work practices, development of work contents, transformation of organisations and introduction of creativity and innovations at work (Collin, Paloniemi and Mecklin, 2010; Collin, Valleala, Herranen and Paloniemi, 2012). As Woods and Woods (2013) criticised, one pitfall of distributed leadership involved its narrow focus on the development of the performative self via measuring the goal attainment, intellectual growth and emotional maturity. If the aim is using distributed leadership to develop organisational members as whole human beings with both psychological and social needs, agency is needed. Agency may help create ideal circumstances for distributed leadership to be realised in schools. Consequently, future research on distributional leadership should focus on how it is exercised in everyday school work 
and on practices among all groups of agents (e.g. officially designated leaders, teachers and students). Therefore, it is also imperative to investigate how agency, both at individual and collective levels, manifests in distributed leadership.

\section{Conclusion}

This meta-analysis set out to enhance the understanding of distributed leadership and provide a research framework for future studies. It intended to continue Bennett et al.'s (2003) review on distributed leadership research from 1996 to 2002. The scope of the present review spanned the 2002-2013 period. It turned out that the research in the field of distributed leadership had become both more independent and broader. Because of such changes, the methodology of this meta-analysis was developed to prudently select a set of contemporary articles on distributed leadership. Besides, there was a need to narrow the focus to primary and secondary education as the meta-analysis had a parallel aim to assist in the design of a distributed leadership study confined to these two levels of education.

Bennett et al (2003) had identified two research gaps, which became the criteria for the selection and analysis of the articles. The results of the present review indicate new information obtained concerning both research gaps but neither of them has been filled satisfactorily. Further studies on the conceptualisation and application of distributed leadership are needed.

One of the main drawbacks for all research on the topic was the lack of a universal definition of distributed leadership. Its absence seemed to impede studies on both the 
conceptualisation and application of distributed leadership. Based on the meta-analysis, we proposed a definition of distributed leadership as an attempt to offer a general framework for future studies.

In the context of the proposed definition of distributed leadership, two main scopes for future studies are suggested. The first one comprises perceiving leadership as a resource from the organisational perspective. This approach seems to have dominated studies on distributed leadership. The second one aims to examine leadership from the viewpoint of the individual as an agency. To date, this approach has not been the focus of distributed leadership research in the same way as the organisational approach has been and could possibly provide novel insights.

\section{Reference}

*Anderson S, Moore S and Sun J (2009) Positioning the principal in patterns of school leadership distribution. In Leithwood, K., Mascall, B., and Strauss, T. (eds) Distributed leadership according to the evidence. New York: Routledge, pp.111136.

*Angelle PS (2010) An organizational perspective of distributed leadership: a portrait of a middle school. RMLE Online: Research in Middle Level Education 33(5): $1-16$.

Archer M (1995) Realist Social Theory: The Morphogenetic Approach. Cambridge, UK: Cambridge University Press.

*Ban Al-Ani AH and Bligh MC (2011) Collaborating with 'virtual strangers' towards developing a framework for leadership in distributed teams. Leadership 7: 219249 
Battilana J (2006) Agency and institutions: the enabling role of individuals' social position. Organization 12(5): 653-676.

*Bennett N, Wise C, Woods PA and Harvey JA, (2003) Distributed Leadership: A Review of Literature. Nottingham: NCSL.

Berger PL and Luckmann T (1991) The Social Construction of Reality. Penguin Books: London.

*Bolden R (2011) Distributed leadership in organizations: a review of theory and research. International Journal of Management Reviews 13: 251-269.

Burrell G and Morgan G (1979) Sociological Paradigms and Organizational Analysis: Elements of the Sociology of Corporate Life. London: Heinemann.

*Bush T and Glover D (2012) Distributed leadership in action: leading high-performing leadership teams in English schools. School Leadership and Management 32(1): 21-36.

*Bush T (2013) Distributed leadership: the model of choice in the $21^{\text {st }}$ century. Educational Management Administration \& Leadership 41(5): 543-544.

Caldwell R (2007) Agency and change: Re-evaluating Foucault's legacy. Organization 14(6): 769-791.

*Camburn E, Rowan B and Taylor JE (2003) Distributed leadership in schools: The case of elementary schools adopting comprehensive school reform. Educational Evaluation and Policy Analysis 25: 347-375.

*Chang I (2011) A study of the relationships between distributed leadership teacher academic optimism and student achievement in Taiwanese elementary schools. School Leadership \& Management 31(5): 491-515.

Ci J (2011) Evaluating agency: A fundamental question for social and political philosophy. Metaphilosophy 42(3): 261-281.

Clegg S (2006) The problem of agency in feminism: A critical realist approach. Gender and Education 18(3): 309-324.

Collin K, Paloniemi S and Mecklin J-P (2010) Promoting inter-professional teamwork and learning - the case of surgical operating theatre. Journal of Education and Work 23(1): 43-63. 
Collin K, Valleala UM, Herranen S and Paloniemi S (2012) Ways of inter-professional collaboration and learning in emergency work. Studies in Continuing Education 34(3): 281-300.

*Copland MA (2003) Leadership of inquiry: building and sustaining capacity through school improvement. Educational Evaluation and Policy Analysis 25: 375-396.

Davies B (2000) (In)scribing body/landscape relations, Alta Mira Press: Walnut Greek.

*Day C, Sammons P, Hopkins D, Harris A, Leithwood K, Gu Q, Brown E, Ahtaridou E and Kington A (2009) The Impact of School Leadership on Pupil Outcomes. London: Final Report DCSF.

*Dinham S, Aubusson P and Brady L (2008) Distributed leadership as a factor in and outcome of teacher action learning. International Electronic Journal for Leadership in Learning 12(4): 1-13.

*Duif T, Harrison C, van Dartel N and Sinyolo D (2013) Distributed Leadership in Practice: a Descriptive Analysis of Distributed Leadership in European Schools. European Policy Network of School Leadership.

*Elmore RF (2003) A plea for strong practice. Educational Leadership 62(3): 6-10.

Eteläpelto A, Vähäsantanen K, Hökkä P and Paloniemi S (2013) What is agency? Conceptualizing professional agency at work. Educational Research Review 10: 45-65.

*Feng DM (2012) 分布式领导之中国意义 [The significance of distributed leadership in China's context]. Educational Development and Research 12: 31-35.

Fenwick T (2006) Escaping/becoming subjects: Learning to work the boundaries in a boundaryless work in S. Billett, T. Fenwick and M. Somerville (eds) Work, Subjectivity and Learning, Springer: Dordrecht, 21-36.

*Fitzgerald T and Gunter H (2006) Teacher leadership? A new form of managerialism, New Zealand Journal of Educational Leadership 21(2): 44-57

Gronn P (2000) Distributed properties: a new architecture for leadership. Educational Management Administration \& Leadership 28: 317-338.

*Gronn P (2002) Distributed leadership as a unit of analysis. Leadership Quarterly 13(4): 423-51. 
*Gronn P (2003) Leadership: who needs it? School Leadership and Management 23(3): 267-290.

*Gronn P (2008) The future of distributed leadership. Journal of Educational Administration 46: 141-158.

*Gronn P (2009a) Hybrid leadership. In Leithwood K, Mascall B and Strauss T (eds) Distributed Leadership according to the Evidence: Routledge, pp.17-40.

*Gronn P (2009b) Leadership configurations. Leadership 5: 381-394.

*Gunter H, Hall D and Bragg J (2013) Distributed leadership: a study in knowledge production. Educational Management Administration \& Leadership 41(5): 555580

*Hargreaves A and Fink D (2008) Distributed leadership: democracy or delivery? Journal of Educational Administration 46: 229-240.

*Harris A (2004) Distributed leadership for school improvement: leading or misleading. Educational Management Administration \& Leadership 32: 11-24.

*Harris A (2005) Leading or misleading? distributed leadership and school improvement. Journal of Curriculum Studies 37: 255-265.

*Harris A (2007) Distributed leadership: conceptual confusion and empirical evidence. International Journal of Leadership in Education 10(3): 315-325.

*Harris A (2008) Distributed leadership: according to the evidence. Journal of Educational Administration 46(2): 172-188.

*Harris A (2009a) Distributed leadership: what we know. In Harris A (ed) Distributed Leadership: Different Perspectives. Dordrecht: Springer, 11-21.

*Harris A (2009b) Distributed leadership and knowledge creation. In Leithwood K, Mascall B and Strauss T (eds) Distributed Leadership according to the Evidence. Abingdon: Routledge, 253-266.

*Harris A (2012) Distributed leadership: implications for the role of the principal. Journal of Management Development 31(1): 7-17.

*Harris A (2013a) Distributed Leadership Matters; Potential, Practicalities and Possibilities. Thousand Oaks CA: Corwin Press. 
*Harris A (2013b) Distributed leadership: friend or foe. Educational Management Administration \& Leadership 41(5): 545-554.

*Hartley D (2007) The emergence of distributed leadership in education: why now? British Journal of Educational Studies 55(2): 202-14.

*Hartley D (2009) Education policy distributed leadership and socio-cultural theory. Educational Review 61:139-150.

*Hartley D (2010) Paradigms: how far does research in distributed leadership “stretch"? Educational Management Administration \& Leadership 38(3): 271-285.

*Heikka J, Waniganayake M and Hujala E (2012) Contextualizing distributed leadership within early childhood education: current understandings research evidence and future challenges. Educational Management Administration \& Leadership 41(1): 30-44.

*Heck R and Hallinger P (2010) Testing a longitudinal model of distributed leadership effects on school improvement. Leadership Quarterly 21: 867-885.

*Hulpia H, Devos G and Rosseel Y (2009a) Development and validation of scores on the distributed leadership inventory. Educational and Psychological Measurement 69(6): 1013-1034.

*Hulpia H and Devos G (2009b) Exploring the link between distributed leadership and job satisfaction of school leaders. Educational Studies 35: 153-171.

*Hulpia H, Devos G and Van Keer H (2009c) The influence of distributed leadership on teachers' organizational commitment: A multilevel approach. Journal of Educational Research 103(1): 40-52.

*Hulpia H, Devos G, Rosseel Y and Vlerick P (2012) Dimensions of distributed leadership and the impact on teachers' organizational commitment: a study in secondary education. Journal of Applied Social Psychology 42(7): 1745-1784.

*Johnson B (2004) Local school micropolitical agency: An antidote to new managerialism. School Leadership and Management 24: 267-286.

*Jing WL (2010) School leadership in two countries: shared leadership in American and Chinese high schools. Dissertation in Arizona State University. 1-178.

*Jäppinen AK and Maunonen-Eskelinen I (2012) Organizational transition challenges in the Finnish vocational education-perspective of distributed pedagogical leadership. Educational Studies 38(1): 9-50. 
*Jäppinen AK and Sarja A (2012) Distributed pedagogical leadership and generative dialogue in educational nodes. Management in Education 26(2): 64-72.

*Lakomski G (2008) Functionally adequate but causally idle: w(h)ither distributed leadership?. Journal of Educational Administration 46: 159-171.

*Law E, Galton M and Wan S (2010) Distributed curriculum leadership in action: a Hong Kong case study. Educational Management Administration \& Leadership 38(3): 286-303.

*Lee M, Hallinger P and Walker A (2012) A distributed perspective on instructional leadership in international baccalaureate (IB) schools. The Journal of Leadership for Effective \& Equitable Organizations 48(4): 664-698.

*Leithwood K, Mascall B, Strauss T, Sacks R, Memon N and Yashkina A (2007) Distributing leadership to make schools smarter: taking the ego out of the system. Leadership and Policy Studies 6(1): 37-67.

*Leithwood K and Mascall B (2008) Collective leadership effects on student achievement. Educational Administration Quarterly 44(4): 529-561.

*Leithwood K, Mascall B and Strauss T (2009a) Distributed Leadership according to the Evidence, Abingdon: Routledge.

*Leithwood K, Mascall B and Strauss T (2009b) New perspectives on an old idea: a short history of the old idea. In: Leithwood K, Mascall B and Strauss T (eds) Distributed Leadership according to the Evidence. Abingdon: Routledge, 1-14.

*Locke EA (2003) Leadership: starting at the top. In: Peaerce CJ and Conger C (eds) Shared Leadership: Reframing the Hows and Whys of Leadership. CA: Sage, 271-284.

*Lumby J (2013) Distributed leadership: the uses and abuses of power. Educational Management Administration \& Leadership 41(5): 581-597.

*MacBeath J (2005) Leadership as distributed: a matter of practice. School Leadership and Management 25(4): 349-366.

*Mayrowetz D (2005, 10-13 November) Perceptions and interpretations of distributed leadership: Implications for leadership development and school improvement. Nashville TN: University Council on Educational Administration Annual Convention. 
*Mayrowetz D (2008) Making sense of distributed leadership: exploring the multiple usages of the concept in the field. Educational Administration Quarterly 44: 424435.

*Mayrowetz D, Murphy J, Louis KS and Smylie MA (2009) Conceptualizing distributed leadership as a school reform: revisiting job redesign theory. In Leithwood K, Mascall B and Strauss T (eds) Distributed Leadership According to the Evidence. New York: Routledge, 167-195.

*Murphy J, Mayrowetz D, Smylie M and Louis KS (2009) The role of the principal in fostering the development of distributed leadership. School Leadership \& Management 29(2): 181-214.

*Oduro GKT (2004) Distributed leadership in schools. Education Journal 80: 23-25.

*Oswald M and Engelbrecht P (2013) Leadership in disadvantaged primary schools: two narratives of contrasting schools. Educational Management Administration \& Leadership 41(5): 620-639.

*Pedersen J, Yager S and Yager R (2012) Student leadership distribution: effects of a student-led leadership program on school climate and community. International Journal of Educational Leadership Preparation 7(2): 1-9.

*Pyhältö K, Pietarinen J and Soini T (2012) Do comprehensive school teachers perceive themselves as active professional agents in school reforms? Journal of Educational Change 13: 95-116.

*Robinson VMJ (2008) Forging the links between distributed leadership and educational outcomes. Journal of Educational Administration 46 (2): 241-256.

*Scribner SMP and Bradley-Levine J (2010) The meaning(s) of teacher leadership in an urban high school reform. Educational Administration Quarterly 46: 491-522.

*Scribner J, Sawyer R, Watson S and Myers V (2007) Teacher teams and distributed leadership: A study of group discourse and collaboration. Educational Administration Quarterly 43(1): 67-100.

*Sentočnik S and Rupar B (2009) School leadership of the future: how the national education institute in Slovenia supported schools to develop distributed leadership practice. European Education 41(3): 7-22.

*Spillane J, Diamond J and Jita L (2003) Leading instruction: The distribution of leadership for instruction. Journal of Curriculum Studies 35(5): 533-543. 
*Spillane J, Halverson R and Diamond J (2004) Towards a theory of leadership practice: a distributed perspective. Journal of Curriculum Studies 36: 3-34.

*Spillane J (2006) Distributed Leadership. San Francisco: Jossey-Bass

*Spillane J, Camburn EM and Pareja AS (2007) Taking a distributed perspective to the school principal's workday. Leadership and Policy in Schools 6(1): 103-125.

*Spillane J and Healey K (2010) Conceptualizing school leadership and management from a distributed perspective. The Elementary School Journal 11(2): 253-281.

*Storey A (2004) The problem of distributed leadership in schools. School Leadership and Management 24: 249-265.

*Timperley HS (2005) Distributed leadership: developing theory from practice. Journal of Curriculum Studies 37(4): 395-420.

*Timperley HS (2009) Distributing leadership to improve outcomes for students. In Leithwood K, Mascall B and Strauss T (eds) Distributed Leadership according to the Evidence. Abingdon: Routledge, 197-222.

*Wallace M (2002) Modelling distributed leadership and management effectiveness: primary school senior management teams in England and Wales. School Effectiveness and School Improvement 13(2): 163-186.

*Watson ST and Scribner JP (2005, 10-13 November) Emergent reciprocal influence: toward a framework for understanding the distribution of leadership within collaborative school activity. Nashville TN: University Council for Educational Administration Annual Convention.

*Watson ST and Scribner JP (2007) Beyond distributed leadership: collaboration interaction and emergent reciprocal influence. Journal of School Leadership 17: 443-468.

*Williams CG (2011) Distributed leadership in South African schools: possibilities and constraints. South African Journal of Education 31(2): 190-200.

*Woods PA (2004) Democratic leadership: drawing distinctions with distributed leadership. International Journal of Leadership in Education: Theory and Practice 7(1): 3-26.

*Woods PA (2005). Democratic leadership in education. London: Sage. 
Woods PA (2011). Transforming Education Policy: Shaping a democratic future. Bristol: Policy Press.

*Woods PA (2013) Drivers to holistic democracy: signs and signals of emergent, democratic self-organising systems. In Weber SM, Göhlich A, Schröer H and Fahrenwald C (eds) Organisation und Partizipation: Beiträge der Kommission Organisationspädagogik. Berlin: Springer VS, pp. 343-356.

*Woods PA, Bennett N, Harvey JA and Wise C (2004) Variabilities and dualities in distributed leadership: findings from a systematic literature review. Educational Management Administration \& Leadership 32(4): 439-457.

*Woods PA and Woods GJ (2013) Deepening distributed leadership: a democratic perspective on power, purpose and the concept of the self. Vodenje $v$ vzgoji in izobraževanju (Leadership in Education) 2: 17-40.

*Wright LL (2008) Merits and limitations of distributed leadership: experiences and understandings of school principals. Canadian Journal of Educational Administration and Policy 69: 1-33. 